\title{
Role of Iron-Containing Compounds in Ayurvedic Medicines for the Treatment of Helicobacter pylori Infection
}

\author{
Yadav Yadevendra ${ }^{1 *}$, Joshi Namrata ${ }^{2}$, Sharma Khemchand ${ }^{3}$
}

${ }^{1}$ Assistant Professor P.G. Department of Rasa Shastra \& Bhaishajya kalpana, Uttarakhand Ayurveda University, Rishikul Campus, Haridwar India ${ }^{2}$ P.G. Department of Rasa Shastra \& Bhaishajya kalpana, Institute of Medical Sciences, Banaras Hindu University,Varanasi India

${ }^{3}$ Professor and Head P.G. Department of Rasa Shastra \& Bhaishajya kalpana, Uttarakhand Ayurveda University, Rishikul Campus, Haridwar India

DOI: $10.36348 /$ sijtcm.2020.v03i04.002

| Received: 03.04.2020 | Accepted: 11.04.2020 | Published: 30.04 .2020

*Corresponding author: Yadevendra Yadav

\section{Abstract}

In Ayurveda, Amla-pitta and Shula are the diseases caused by improper digestion of food. Though medical science considered the excessive use of NSAID and Helicobacter Pylori are two leading causes. Infection of $H$. pylori progresses from gastritis to more severe upper gastrointestinal tract disorders. H. pylori colonize the stomachs of more than half of the human population. In the Vrayatrya (Triad of Major Ayurvedic texts) Amla-pitta is not mentioned. However, Acharya Sushruta, Harita, Kashyap has described Shula in their treatise. For this disorder, single and compound herbal drugs were prescribed. Moreover, Acharya Chakradutta started the use of Iron and calcium-containing compound in compound formulations for the first time. Calcium carbonate is a rapidly acting acid neutralizer. However, the role of iron in these disorders is not clear in terms of modern pharmacology. Iron is an excellent carrier of oxygen, so it ceases the suitable conditions for the survival of micro-aerophilic organisms like H. Pylori. Acharya charka termed this principle of treatment as Prakarti vighata in context of Krimi Chikitsa. So Lauha Bhasma and their compound formulation might be efficiently inhibiting Multi-Drug Resistant Helicobacter pylori.

Keywords: Amla-pitta, H. pylori, Peptic ulcer, Micro-aerophilic, Prakriti-vighata, Shula.

Copyright @ 2020: This is an open-access article distributed under the terms of the Creative Commons Attribution license which permits unrestricted use, distribution, and reproduction in any medium for non-commercial use (NonCommercial, or CC-BY-NC) provided the original author and source are credited.

\section{INTRODUCTION}

In Ayurvedic system of medicine, Iron compounds and its containing formulations were abundantly used in medicine since the Samhita period, i.e., $2^{\text {nd }}$ century AD. Acharya Charaka uses Mandura, Rajat makshika \& Swarna makshika in the treatment of Pandu Rog (anaemia) for internal preparation [1]. This is the beginning of an internal intake of iron and its compound in the treatment of various diseases. In the $11^{\text {th }}$ century, Acharya chakarpanaidatta, in his book chakradatta first time, mentioned the use of compounds of iron in the treatment of Shula[2] and Parinam Shula (colic pain). In the $18^{\text {th }}$ century Author of Yogratnakara use Madura in ample of Yogas (formulation), like Manduraavleha Taramadura, Bhimamandura, Shatavari Mandura and Lauha Guggulu etc. in Shola Chikitsa[3]. In the chapter of Shula chikitsa, most of the formulation contains Calcium carbonate-containing compound Shambuka (conch shell), and the iron oxide-containing compound is used. However, in most preparations contains iron oxide as one of the chief ingredients. Burning epigastric pain aggravated by fasting and improved with meals is a symptom complex associated with peptic ulcer disease [4]. Ayurvedic practitioners of these present days correlate intestinal colic with Shula, Parainam Shula, Annadrava Shula and Kukhashi Shula, based on time of onset and abdominal region respectively[5].

The Prevalence of $H$. pylori varies throughout the world and depends to a great extent on the overall standard of living in the region. In developing parts of the world, $80 \%$ of the population may be infected by the age of 20 , whereas the prevalence is $20-50 \%$ in the industrialized countries [6]. The risk factors for $H$. pylori are (i) birth or residence in a developing country, (2) domestic crowding, (3) unsanitary living conditions, (4) unclean food or water and (5) exposure to gastric contents of an infected individual. So countries having low socioeconomic status, crowding and poor hygiene are likely to infected with the causative bacterium. That is why incidences of Peptic Ulcer disorders are drastically declined due to improvements in living standards and increased use of antibiotics[4]. 
The discovery of Helicobacter pylori in 1982 [7] was the turning point of a revolution concerning the concept of management of gastroduodenal diseases. It is nowadays well accepted that the peptic ulcer is a most common infectious disease of the stomach, and entirely consensus conferences agree that the causative agent, $H$. pylori, must be treated with antibiotics [8]. In 2005 the Nobel Prize in Physiology or Medicine to B. Marshall and R. Warren for the discovery of $H$. pylori and its role in stomach diseases. In the list of Nobel prizes, this is only the $3^{\text {rd }}$ time that the discovery of a bacterium has been acknowledged [9]. The standard empirical triple therapy for $H$. pylori proposed at the first Maastrict conference on management of $H$. pylori infection [10]. has become widely used throughout the world [11]. Antibiotic resistance is a continually evolving process, and numerous studies have been shown that the prevalence of $H$. pylori resistance varies significantly from country to country and even between regions within the same country [12].

\section{Amla-pitta Vis-a-vis hyperacidity:}

It is complicated to correlate any disease with any vyadhi (disease) mention in the Ayurveda. However, based on signs, symptoms and line of treatment mention in Ayurveda and modern medical science can be able to establish their similarity. So, in the same way, Amla-pitta cannot be correlated with one Acid Reflux syndrome which comprises with GERD, Gastritis, dyspepsia, peptic ulcer, hyperacidity [13]. Indigestion, lethargy, nausea, acid eructation, heartburn $\&$ Anorexia, etc. are cardinal features of the disease [14].

\section{Shula ( Abdominal colic):}

Abdominal pain is common to many gastrointestinal disorders, including duodenal ulcer and gastric ulcer. Epigastric pain described as burning or gnawing discomfort is also described as an ill-defined, aching sensation or as a hunger pain. The futuristic pain pattern in DU occurs 90 minutes to $3 \mathrm{hr}$ after a meal and is frequently relieved by food. Pain that disturbs the sleep of the patient, especially between midnight \& 3 A.M., is the most discriminating symptom. The pattern of pain in GU patients may be unlike that in DU patients, where discomfort may be precipitated by food. Ulcers detect by endoscopic method reveals that the lesser than $30 \%$ of patients having dyspepsia. Regardless of this, $40 \%$ of these individuals with typical ulcer symptoms had an ulcer crater, and $40 \%$ had gastroduodenitis on endoscopic examinations. Pain may be arises due to acid-induced activation of chemical receptors in the duodenum, enhanced duodenal sensitivity due to bile acids and pepsin or altered gastroduodenal motility [4]. This pain can be correlated with Annadrava \& Parinam Shula.

\section{The Bacterium:}

The bacterium, initially named Campylobacter Pyloridis, found most commonly in the deeper portions of the mucous gel coating the gastric mucosa or between the mucous layer and the gastric epithelium. It may attach to gastric epithelium but under normal circumstances does not appear to invade cells. It is strategically designed to live within the aggressive environment of the stomach. Transmission of $H$. pylori occurs from person to person, following an oral-oral or faecal-oral route [4]. H. pylori is a microaerophilic, capnophilic noninvasive, non-spore-forming, spiral, Sshaped, flagellated gram-negative rod measuring approximately $3.5 \times 0.5 \mu \mathrm{m}$ in size. This organism is capable of transforming into a coccoid form[15], which represents a dormant state that may facilitate survival in adverse conditions $H$. pylori grows best at a slightly acidic pH, i.e. 5 to 6 [16]. An enzyme called urease produces by the bacterium, which splits urea into carbon dioxide and ammonia. While shielding the bacterium from the acidity of the stomach, the ammonia also damages the protective mucous layer of the stomach and the underlying gastric cells. H. pylori also produce catalase, an enzyme that may protect the microbe from the phagocytosis process of neutrophils along with several adhesion proteins that allow the bacterium to attach itself to gastric cells [17].

The other Helicobacter species possibly reside in the stomach of the human is Helicobacter heilmannii, earlier known as Gastrospirillum hominis. This bacterium is usually found in the stomachs of pets (cats, dogs and pigs). It rarely colonizes in the humans and is considered a zoonosis [18]. This organism is nonculturable on standard media; it can essentially be cultured in vivo by introducing it into the mouse stomach [19]. For the first time, Andersen et al. in 1996 grow Helicobacter heilmannii from a 23 yrs patient suffer from dyspepsia on the same plate medium used in their laboratory to grow $H$. pylori, and growth occurred within five days in a standard microaerobic atmosphere. Thus, only 10 to $15 \%$ of the bacteria exhibited a typical morphology from primary culture, contrary to the majority after subculture [23]. This positive culture on a plate for this bacterium which was later identified as Helicobacter bizzozeronii indeed [24].

\section{Diseases caused by $\boldsymbol{H}$. pylori:}

Essentially all $H$. pylori colonized persons have gastric inflammation, but more than $80 \%$ of duodenal ulcers and $60 \%$ of gastric ulcers are related to its colonization, most of the remainder being due to Nonsteroidal anti-inflammatory drugs (NSAIDs).The particular result of $H$. pylori infection is determined by a complex interplay between bacterial and host factors. Apart from important accounting factors for gastritis, Peptic ulcer disease, some nested case-control studies have shown that $H$. pylori colonization is a risk factor for adenocarcinomas of distal stomach, gastric MALT lymphoma and gastric cancer. These sites are noble for the survival of this microbe due to less vascularity.[4] Most of the infected patients will not develop any 
clinically significant complications, $H$. pylori infection confers a $1-10 \%$ risk of developing gastric or duodenal ulcers, $0.1 \%$ - $3 \%$ Risk of developing gastric adenocarcinoma and $0.01 \%$ of developing mucosaassociated lymphoid tissue (MALT) Lymphoma [22].

A peptic ulcer disease encompasses both duodenal and gastric ulcers. Ulcers are defined as a breach of the mucosal surface $>5 \mathrm{~mm}$ in size, with penetration to the submucosa. Duodenal ulcers and gastric ulcers show many common features of pathogenesis, diagnosis, and treatment, but several factors distinguish them from one another. Often, the occurrence of duodenal ulcers most in the first portion of the duodenum with $\sim 90 \%$ located within $3 \mathrm{~cm}$ of the pylorus. They are usually $<1 \mathrm{~cm}$ in diameter but can occasionally reach 3 to $6 \mathrm{~cm}$. In contrast to duodenal ulcers, gastric ulcers are most often found distal to the junction is variable, but in general, the antral mucosa extends about two-thirds of the distance of the lesser curvature and one-third the way up the greater curvature. Benign gastric ulcers are quite rare in the gastric fundus and are histologically similar to duodenal ulcers [4].

\section{Other diseases caused by $\boldsymbol{H}$. pylori:}

It has also been implicated in a variety of body systems like vascular conditions including ischemic heart disease [23], ischemic cerebrovascular disorders, [24] and functional vascular disorders caused by vascular dysregulation (e.g., Raynaud phenomenon and migraine) [25] and with some autoimmune conditions such as Sjögren syndrome[26].

The connection between Helicobacter pylori infection and eye diseases has been increasingly reported in the research literature. The inference of this bacterium in chronic eye diseases, such as blepharitis, glaucoma, central serous chorioretinopathy and others, has been hypothesized [27]. This could be the possible reason for using the same preparation in the pain of gastric origin and eye disorder. All ingredients and their indications of Saptaamita Lauha and Lauha churna are identicals, and even the whole verse is the same. The only difference is that the former formulation was mention in Parinam Shula by Chakradutta[28] while later was mention in Netraroga Chikitsa (Treatment of Eye Disease) of Yoga Ratnakar [29]. This medicine is frequently in use for eye disease these days.

\section{Treatment of $\boldsymbol{H}$. pylori in medical science:}

$H$. pylori has been designated a class I carcinogen by the World Health Organization [30]. Patients with uncomplicated dyspepsia are managed using a "test and treat" strategy [31]. Eradication of $H$. pylori infection provides a long term cure for both gastric and duodenal ulcers in most of the patients whose ulcers are not linked with Non-steroidal antiinflammatory drug use. Earlier from the discovery of $H$. pylori, the therapy of PUD disease was centred on the old dictum Schwartz of "no acid, no ulcer". Though acid secretion is still significant in the pathogenesis of PUD, eradication of $H$. pylori and therapy/ prevention of NSAID-induced disease is the mainstay. So Acid neutralizing/Inhibitory Drugs (Aluminum hydroxide \&Magnesium hydroxide), $\mathrm{H}_{2}$ Receptor antagonist (ranitidine and famotidine) and Proton Pump inhibitors (Omeprazole and pantoprazole) are used for this purpose. Cryoprotective agent likes sucralfate providing physiochemical barrier impending further tissue injury by acid and pepsin. Bismuth containing preparations also provide ulcer coating [4].

In the therapy of H.Pylori, Multiple drugs have been evaluated. Any single agent is not effective in eradicating the organism. Combine therapy for 14 days provides the greatest efficacy. The common conclusion arrived at by numerous consensus conferences (National Institutes of Health Consensus development, American Digestive Health Foundation international Updates Conference, European Maastricht Consensus and Asia Pacific Conference) is that H. pylori should be eradicated in patients having PUD documented [4]. The agents used with the greatest frequency contain amoxicillin, tetracycline, clarithromycin metronidazole, and bismuth compounds [6]. Current Regimens consist of a PPI or Ranitidine, Bismuth citrate and two or three Antimicrobial Agents given for 7-14 days. However, the results of antibiotic resistance in an increased failure rate of therapies [32].

\section{Iron-containing formulation in Ayurveda:}

Various formulations for Shula and Amla-pitta were stated by the ancient Ayurvedic scholars. Some herbs are antispasmodic, carminative, bactericidal or bacteriostatic. Some Ksahar (alkali) like Sajji kshar, Narikala Lawan (medicine made by coconut) or Arka Lawan (medicine prepared by calotropis procera) and calcium carbonate were used to neutralize the acidity of the stomach. However, Ayurvedic text written after $11^{\text {th }}$-century Iron-containing compounds were frequently used in the compound formulations. In Chapter of Parinam-Shula of Chakradatta, the very first reference of iron (Lauha) and its slag (Madura) [33] is used in abdominal colic. Some formulations are as Saptaamrita Lauha, Koladi Madura, Bhima Vatak Mandura, Kshira Mandura, Satawari Mandura, Tara Mandura, Mandura Guda, Rasa Mandura, Triphala Lauha, Dhatri Lauha etc. 
Table-1: Various Iron-containing formulations

\begin{tabular}{cccc}
\hline S. No & Formulation & Name of text & Percentage of iron \\
\hline 1 & Kamdudha Rasa & Siddha Priyog Sangraha & 14.3 \\
\hline 2 & Lagu Sutshekar Ras & Siddha Priyog Sangraha & 66.6 \\
\hline 3 & Amla pittaantaka Lauha & Rasendra Chintani & 16.7 \\
\hline 4 & Shatawari Lauha & Bhasjaya Ratanawala & 05 \\
\hline 5 & Chatusama Lauha & Yoga Ratnakar & 25 \\
\hline 6 & Dhatri Lauha & Chakradatta & 28.6 \\
\hline 7 & Shanker Lauha & Bhava Prakash & 10 \\
\hline 8 & Tridosha Solahara curna & Yoga Ratnakar & 20 \\
\hline 9 & Saptamrita Lauha & Chakradatta & 20 \\
\hline 10 & Triphala Madura & Raendra kama denu & 100 \\
\hline 11 & Leela vilas Rasa & Raendra kama denu & 20 \\
\hline
\end{tabular}

About 30 iron and iron-containing formulations are compiled in Bharat Bhasajaya Ratnakar[34].

\section{Chemical Nature of Lauha Bhasma and Mandura:}

Mandura is a metallic oxide-cum-silicate of iron, generally having the composition $\mathrm{Fe}_{2} \mathrm{SiO}_{4}$ and commonly called Slag [35]. In Ayurveda, Mandura (incinerated iron oxide) has been frequently utilized since the Samhita period ( $2^{\text {nd }}$ century BC to $4^{\text {th }}$ century AD), and its use has been found increased after the $8^{\text {th }}$ century AD. Various research studies were carried out on Pharmaceutical, Characterization and Pharmacological and Toxicological study of Lauha Bhasma and Mandura Bhasma. Phase identification of Mandura Bhasma reveals that it is the oxide of iron $\mathrm{Fe}_{2} \mathrm{O}_{3}$ and $\mathrm{Fe}_{3} \mathrm{O}_{4}$ (Magnetite) is found in the majority.
$\mathrm{Fe}_{2} \mathrm{O}_{3}$ is found in its most stable form of $\alpha-\mathrm{Fe}_{2} \mathrm{O}_{3}$ [36, 37]. Some other studies also show that it has the only presence of Hematite $\left(\mathrm{Fe}_{2} \mathrm{O}_{3}\right)$ in the primary phase, while Iron Manganese oxide hydroxide [38] and $\mathrm{SiO}_{2}$ [39] in the minor phase. One possible reason behind the difference in the minor phase may be due use of different intermediate drugs/ media used for Shodhana (Purification) and Marana (Incineration) in the processing.

The XRD pattern of Lauha Bhasma shows that iron oxide is present in the form that iron oxide is majorly present in the form of $\mathrm{Fe}_{2} \mathrm{O}_{3}$ and $\mathrm{Fe}_{3} \mathrm{O}_{4}$ (Magnetite)[40]. $\mathrm{Fe}_{3} \mathrm{O}_{4}$ is unstable form of Iron oxide. So after some time, it is converted into $\mathrm{FeO}$ and $\mathrm{Fe}_{2} \mathrm{O}_{3}$. Due to using of Sulfur-containing media Minor Phase shows FeS and Iron Manganese oxide hydroxide [38].

Table-2: Percentage of Iron to Oxygen ratio in different oxides of Iron.

\begin{tabular}{|l|l|l|l|}
\hline Name & Formula & \% wt of Fe & Ratio of O \& Fe \\
\hline Hematite & $\mathrm{Fe}_{2} \mathrm{O}_{3}$ & 70 & 1.5 \\
\hline Magnetite & $\mathrm{Fe}_{3} \mathrm{O}_{4}$ & 72.4 & 1.33 \\
\hline Wustite & $\mathrm{FeO}$ & 76.6 & 1.05 \\
\hline Iron & $\mathrm{Fe}$ & 100 & 0 \\
\hline
\end{tabular}

\section{Oxygen carrying capacity of iron:}

Iron, copper and manganese belong to transition elements. Chemically they show variable valency and a strong tendency to form coordination compounds. Iron is the most prevalent redox-active metal [41]. Iron oxide is an amphoteric oxide, commonly used as an absorbent and as a catalyst. The reduction in behaviour and the degree of reduction of iron species were highly important in some chemical processes. The reduction of hematite $\left(\mathrm{Fe}_{2} \mathrm{O}_{3}\right)$ has widely studied and involved different mechanisms depending upon various factors such as temperature, reduction gas used particle size, crystallinity and additive to $\mathrm{Fe}_{2} \mathrm{O}_{3}$. So, these are the requirement to improve the ability of Oxygen storage \& releasing. The reduction behaviour of the Iron oxide may vary by reduction gaseous $\left(\mathrm{H}_{2} \& \mathrm{CO}\right)$. Hematite $\left(\alpha-\mathrm{Fe}_{2} \mathrm{O}_{3}\right)$ being a major and thermodynamically most stable oxide among the 16 identified iron oxide compounds[42].

Iron has various vital functions in the mammalian body. It acts as a carrier of oxygen to the tissues from the lungs by the haemoglobin of red blood cell. Iron present in the body is mostly in erythrocytes as haemoglobin; a molecule comprises of four units, each containing one protein chain and one heme group. The structure of the haemoglobin allows it to be fully loaded with oxygen in the lungs and partially unloaded in the tissues. The iron-containing oxygen storage protein in the muscles is myoglobin which is quite similar in structure to haemoglobin but has only one globin chain and one heme unit. Various ironcontaining enzymes in the cytochromes, also have one one globin protein chain and heme group. These enzymes serve as electron carriers within the cell, and 
their structures do not permit reversible loading and unloading of oxygen[43]. Most iron-reducing bacteria are capable of using several terminal acceptors besides ferric-iron [44] but their distinguishing characteristic where the sole grow under anaerobic conditions where the sole $\mathrm{e}^{-}$acceptor is $\mathrm{Fe}^{+++}$. Terminal electron acceptors are insoluble and cannot be taken up cytoplasm rich in $\mathrm{NO}_{3}{ }^{-}, \mathrm{SO}_{4}{ }^{2-}, \mathrm{HCO}_{3}{ }^{-}$. Organisms that was capable of reducing iron were first cultured in 1987.

\section{Microbial survival on $\mathrm{O}_{2} \&$ Fe:}

Recent studies also showed that $H$. pylori infection can contribute to iron deficiency anaemia [45] According to several studies H.pylori requires iron to survive and may play an important role in unexplained iron deficiency anaemia [46] It is now clear that human lactoferrin and heme supports full growth of $H$. pylori even in a medium with no other iron resources [47]. One of the first lines of defence against bacterial infection is the cover-up of nutrients to prevent outward bacterial growth in a process termed nutritional immunity. Sequestration of nutrient iron is the most significant form of nutritional immunity [48]. In most of the vertebrate, iron is intracellular, sequestered inside iron-containing protein ferritin or complexed with porphyrin ring of heme as a cofactor of haemoglobin or myoglobin. Moreover, the aerobic environment and neutral $\mathrm{pH}$ of serum ensure that extracellular iron is insoluble, and hence the main difficulty is to access by invading pathogens. This difficulty is upsurge by the serum protein transferrin, which binds iron with an association constant of approximately $10^{36}$ [49]. Taken together, these factors provide free iron available to invading bacteria is vastly less than what is required to replicate and cause disease. Most pathogens have not evolved this simple defence strategy and instead circumvent iron withholding through high-affinity of iron uptake operations that compete with host-mediated sequestration. These uptake systems may be divided into three main categories: siderophore based systems, heme acquisition systems, and transferrin/lactoferrin receptors; Siderophores are low molecular weight ironbinding complexes that are secreted from bacteria. Siderophores bind iron with an association constant that can exceed $10^{50}$, enabling bacteria to compete with iron sequestration by transferrin and lactoferrin [50]. Although the existence of siderophores has not been described in $H$. pylori, it has been revealed that this bacterium can bind and utilize several hosts ironbinding molecules as iron sources [47]. Heme acquisition systems typically involve surface receptors that recognize either heme or heme bound to hemoproteins such as haemoglobin or hemopexin. Heme is then removed from hemoproteins and transported through the envelope of bacteria into the cytoplasm. Once inside the cytoplasm, the iron is released from heme through the action of heme oxygenases or reverse ferrochelatase activity [51]. In addition to acquiring iron from transferrin and lactoferrin through siderophore-based mechanisms, some bacteria are capable of direct recognition of these host proteins. The most well-studied transferrin and lactoferrin receptors are present in pathogenic members of the Neisseriaceae and Pasteurellaceae [50]. This is particularly relevant because $H$. pylori colonize in the mucosal lining of the gaster where free iron is readily sequestered by host iron-binding proteins such as transferrin and lactoferrin. The recent progress of an iron-deficient chemically defined medium unequivocally demonstrated that $H$. pylori could gain iron from fully saturated (holo) lactoferrin and. However, the authors showed that H. pylori bind the apo-form of these two proteins with higher affinity than the holo-forms. Subsequently, H. pylori cannot use iron from partially saturated $(<75 \%)$ transferrin or lactoferrin and, thus, is unable to uptake iron from serum. Owing to this, the inability to siphon iron from serum has suggested blocking $H$. pylori virulence by checking its growth in the bloodstream, where the presence of apo-lactoferrin and apo-transferrin is relatively high [52]. In keeping this fact, the ability of H. pylori to use haemoglobin as an iron source is well documented [53]. The regulatory mechanism of iron homeostasis is mediated by the ferric uptake regulator (Fur), which fundamentally regulates transcription of genes involved in iron acquisition and storage in response to changes in iron availability[54]. However, Fur also regulates gene expression in response to low $\mathrm{pH}$ [55], oxidative stress[56] and salt[57]. Therefore, collectively, Fur plays a master role in the adaptation of $H$. pylori to the hostile environment of the stomach. The spirugenic iron oxide nanoparticles exhibited good antibacterial activity against multidrug-resistant Helicobacter pylori [58].

H. pylori show aerotaxis response to optimal oxygen concentration like Magnetotactic bacterias (MTB) [59].

Iron is a crucial element for most life on the planet, including human beings by sharing in a wide variety of metabolic processes, including oxygen transport, DNA synthesis, electron transport and as well as its role as a co-factor within iron-sulfur clusters and he makes it a necessity for nearly every living organism including $\mathrm{H}$ pylori[60]. Iron is needed for several highly composite processes that endlessly take place at a molecular level and that are vital to human life, e.g. the carriage of oxygen around your body. Haemoglobin and myoglobin are oxygen transporter molecules in all vertebrates [61].

Dietary iron is present either as haeme or as inorganic iron. Haeme iron is better absorbed (up to 30 $\%)$ than inorganic iron $(\sim 5 \%)$. Inorganic iron is usually in the ferric form; it needs to be reduced to ferrous form before absorption can take place. Absorption of haeme iron is largely independent of other foods simultaneously ingested, but that of inorganic iron is 
affected by several factors. Acidic medium favours by helping in dissolution and reduction of ferric iron. While alkaline medium and phosphate reduces iron absorption. Iron is plentiful in the human body, but it is bound to intracellular \& extracellular components. This strict iron homeostasis leads to the unavailability of free iron for pathogenic bacteria in the host body [62].

\section{Probable mode of action of iron-containing compounds}

Oxidative Stress Gated by Fenton and Heber Weiss Reactions. The Haber-Weiss reaction produces - $\mathrm{OH}$ (hydroxyl radicals) from $\mathrm{H}_{2} \mathrm{O}_{2}$ (hydrogen peroxide) and superoxide $\left(\bullet \mathrm{O}_{2}-\right)$ catalyzed by iron ions [63]. Iron in the ferrous state is an electron donor, and in the ferric state, it is an electron acceptor. Therefore, Iron can donate and accept electron by means that it can catalyze the renovation of hydrogen peroxide into free radicals. Free radicals can cause damage to a wide variety of cellular structures that ultimately kill the cell. This reaction has long been previously studied and revived in different contexts, including radiochemistry, free radicals, organic chemistry, and water radiolysis. In 1970, with the emerging curiosity for the effect of free radicals onto the ageing process of biological cells due to oxygen $\left(\mathrm{O}_{2}\right)$, it was projected that the Haber-Weiss reaction was a basis of radicals accountable for cellular oxidative stress. However, this hypothesis was then disproved by several previous research studies [64]. The oxidative stress toxicity is not caused by the Haber-Weiss reaction as a whole, but by the Fenton reaction, which is a specific portion of it. The chemical reaction is kinetically slow but is catalyzed by dissolved iron ions. The first step of the catalytic cycle involves the reduction of the ferric $\left(\mathrm{Fe}^{3+}\right)$ ion into the ferrous $\left(\mathrm{Fe}^{2+}\right)$ ion:

$$
\mathrm{Fe}^{3+}+\cdot \mathrm{O}_{2}{ }^{-} \rightarrow \mathrm{Fe}^{2+}+\mathrm{O}_{2}
$$

The second step is the Fenton reaction:

$$
\mathrm{Fe}^{2+}+\mathrm{H}_{2} \mathrm{O}_{2} \rightarrow \mathrm{Fe}^{3+}+\mathrm{OH}^{-}+\cdot \mathrm{OH}
$$

Net reaction:

$$
\cdot \mathrm{O}^{2-}+\mathrm{H}_{2} \mathrm{O}_{2} \rightarrow \cdot \mathrm{OH}+\mathrm{OH}^{-}+\mathrm{O}_{2}
$$

Finally, the chain is terminated when a ferrous ion scavenges the hydroxyl radical:

$$
\mathrm{Fe}^{2+}+\mathrm{HO}^{0}+\mathrm{H}^{+} \rightarrow \mathrm{Fe}^{3+}+\mathrm{H}_{2} \mathrm{O} \text { (termination) }
$$

As the Fenton reaction depends on the concurrent presence in the solution of dissolved $\mathrm{Fe}^{2+}$ and $\mathrm{Fe}^{3+}$ ions, its kinetics is influenced by the particular solubilities of both reacting species whose are directly function of the solution $\mathrm{pH}$. The ferric ion concentration is the limiting aspect of the reaction rate. The reaction can only proceed at a rapid rate under sufficiently acidic conditions. At high $\mathrm{pH}$, under alkaline conditions, the reaction considerably slows down because of the precipitation of $\mathrm{Fe}(\mathrm{OH}) 3$ which notably lowers the concentration of the $\mathrm{Fe}^{3+}$ species in solution. Moreover, the $\mathrm{pH}$ value also directly influences the acid-base dissociation equilibrium involving the hydroperoxyl and the superoxide radicals. The optimal solution $\mathrm{pH}$ for homogenous as well as heterogenous has 2.8 to 3.2 [65]. The $\mathrm{pH}$ of 1.5 to 3.5 of gastric acid is [66]. So this is a favourable site for the reaction.

The central mechanism that caused the antibacterial activity by the particles might be through oxidative stress caused by ROS $[67,68]$. ROS includes radicals like superoxide radicals $\left(\mathrm{O}_{2}^{-}\right)$, hydroxyl radicals $(-\mathrm{OH})$ and hydrogen peroxide $\left(\mathrm{H}_{2} \mathrm{O}_{2}\right)$ could be the reason damaging the proteins and DNA in the bacteria. The ferrous irons reacted with the produced $\mathrm{H}_{2} \mathrm{O}_{2}$ subsequently through Fenton reaction and thus leading to creating hydroxyl radicals which damage the biological macromolecules.

It is believed that microorganisms carry a negative charge while metal oxides carry a positive charge. This creates an "electromagnetic" attraction between the microbe and the treated surface. Once the contact is established, the microbe is oxidized and died instantly. Generally, it is believed that nano-materials release ions, which react with the thiol groups $(-\mathrm{SH})$ of the proteins present on the bacterial cell surface. Such proteins protrude through the bacterial cell membrane, allowing the transport of nutrients through the cell wall. Nano-materials inactivate the proteins, decreasing the membrane permeability and eventually causing cellular death [69]. Nano- and sub-micro-sized iron oxide nanoparticles did not significantly produce intracellular Reactive Oxygen Species (ROS) due to the surface charge of nanoparticle and their sizes. The smaller size of IONs was found more cytotoxic than those of larger size. Moreover, carboxyl-coated IONs caused higher cytotoxicity in comparison with amine-coated IONs[70].

Iron oxide has various isomers like $\mathrm{Fe}_{2} \mathrm{O}_{3}$ $(\alpha, \gamma, \varepsilon),\{$ Hematite $\}, \mathrm{FeO}, \mathrm{Fe}_{3} \mathrm{O}_{4}\{$ Magnetite $\}$ etc. $\alpha-$ $\mathrm{Fe}_{2} \mathrm{O}_{3}$ is rhombohedral, $\gamma-\mathrm{Fe}_{2} \mathrm{O}_{3}$ is cubical and $\varepsilon-\mathrm{Fe}_{2} \mathrm{O}_{3}$ is rhombic in crystalline geometry [80]. Fenton reactions in heterogeneous processes have used several minerals or chemical forms of iron. The iron oxidation state of furthermost natural minerals such as goethite and hematite is $3+(2+$ for magnetite $)$. Many researchers have informed that magnetite is a more effective catalyst than hematite or goethite for heterogeneous Fenton reactions because the magnetite has a combination of $\mathrm{Fe}^{2+}$ and $\mathrm{Fe}^{3+}$ oxidation states. The combination of $2+$ and $3+$ oxidation states in magnetite enhances the production rate of $\mathrm{OH}$ radicals because the reaction rate of $\mathrm{H}_{2} \mathrm{O}_{2}$ with $\mathrm{Fe}^{2+}$ sites is significantly higher than the rate with $\mathrm{Fe}^{3+}$ sites. Additionally, the octahedral site of the magnetite structure is a very versatile redox site that can accommodate both $\mathrm{Fe}^{3+}$ and $\mathrm{Fe}^{2+}$. Therefore, the $\mathrm{Fe}^{3+}$ can be easily reduced to $\mathrm{Fe}^{2+}$ without structural constraints. Valentine and Wang 
proposed that the surface area of iron oxide accounts for the difference in reaction activity[71].

\section{Lysis of cell wall}

Another possible mechanism of action is that the metal nanoparticles are carrying the positive charges and the microbes have the negative charges which create the electromagnetic attraction between the nanoparticles and the microbes. When the attraction is made, the microbes get oxidized and die instantly[72]. Generally, the nanomaterials release ions, which react with the thiol groups $(-\mathrm{SH})$ of the proteins present on the bacterial cell surface which leads to cell lysis [73].

\section{Singlet Oxygen (O2):}

It is an electronically high excited, meta-stable state of molecular oxygen and is a highly reactive toxic reactive oxygen species [74]. It is a highly potent oxidizing agent that can cause DNA damage and tissue damage [75]. When their growth was studied about the oxygen concentration, optimal growth occurred with a $\mathrm{pO}_{2}$ of 2 to $10 \mathrm{KPa}$, whereas no growth occurred at a $\mathrm{pO}_{2}$ of air [76]. So, excessive oxygen damages the Microaerophilic niche. This line of treatment called as Prakartivighata Chikitsa (establish of unfavourable condition for survival) of Krimi (Harmful microorganism/ Insect), enlighten by Acharya Charka[77].

H. pylori are microaerophilic, i.e. it prefers a minimal amount of oxygen and is inhibited by the oxygen present in the air. Possibly that is the reason why it does not colonize the fundus region of the stomach. Similarly, in the colon, it can inhibit the vegetative forms of Entamoeba histolytica, another anaerobic pathogen of the gut.

Cytotoxic activity of Iron oxide Nanoparticles Nano- and Submicro-sized IONPs did not significantly produce intracellular reactive oxygen species. The smaller size if IONPs were found more cytotoxic than those of large size. A study was conducted by Sharaf, Abbas and Tarek et al. in vitro cytotoxic activity test by MTT assay measurement investigation, no cytotoxic effect detected for SIONs at all tested concentrations which ranged from 100 to $0.78 \mu \mathrm{g} / \mathrm{ml}$ on the human epithelial cell line. Cytotoxicity examination revealed safe use of SIONs, which may be due to the presence of positively charged amino groups in protein coating SIONs as figured out in FTIR analysis. Moreover, TEM analysis demonstrated that the mean average length and width for SIONs were 137.51 and $31.04 \mathrm{~nm}$, respectively, which considered relatively large in size [58]. Scanning Electron Microscopy (SEM) studies Of Lauha Bhasma showed that the grains were uniformly arranged in agglomerates of sizes 200-300 nm [39]. A similar finding was found in another study that the Smallest and largest particle size of Lauha Bhasma was found between $14 \mathrm{~nm}$ to $500 \mathrm{~nm}$ [37, 78]. Neither toxicity and nor mortality was observed in albino rats up to 100 times the therapeutic dose (TD) during acute toxicity study of Lauha Bhasma[79].

\section{DISCUSSION}

In Ayurveda Lilavilas Rasa, Dhatri Lauha, Sutrashaker Rasa, Kamdudha Rasa, Amla pittantaka Rasa and Triphala Lauha are used in the treatment of Hyperacidity and Saptamrita Lauha in eye diseases from a long time. However, any scientific literature is not available for this so far as to understand the mode of action of the same. All these are composite drugs of iron oxide in Nano-sized form. Method of preparation of Bhasma is the traditional process of manufacturing Nano-sized metallic medicine by green synthesis technique. Iron oxide can generate Hydroxyl radical $(\cdot \mathrm{OH})$, superoxide $\left(\cdot \mathrm{O}^{2-}\right)$ and oxygen molecule in the presence of moderate to low acidic $\mathrm{pH}$. These reactive oxygen species seems to kill microbes, but diatomic oxygen generation and transportation is the strongest reason than the previous method. Myoglobin and haemoglobin are useful due to oxygen-carrying and transportation in the available binding sites for oxygen in Iron. Micro-aerophilic nature of Helicobacter pylori of bacterium that colonizes the mucous lining of the human stomach is not able to survive in oxygen-rich surroundings. So, iron oxide works as bacteriostatic as well as bactericidal medicine. This evidence indicated that ancient Indian clinician uses Iron-containing compound in their choice of therapy for the management of $H$. pylori infection. This might be the most cost-effective treatment of $H$. pylori-related to GIT and diseases other than GIT. Some study shows that the emerging rates of antimicrobial resistance represent a significant challenge in the management of H. pylori. Moreover, resistance development to iron seems almost impossible because it directly invades the niche for the bacterium. This perception is supported by the fact that air is present in the fundus of the stomach which remains $H$. pylori colonization free region in the fundus region By the same way, it may be helpful in other associated disease like MALT, adenocarcinoma, chronic gastritis and several eye diseases. Refractory iron-deficiency anaemia (IDA) is quite common in H.Pylori infected individuals. Therefore not only it wipes out $H$. pylori but also cure IDA. Further, cellular oxygenation also plays a role in the treatment of cancer.

\section{CONCLUSION}

Herbo-mineral formulation containing Mandura Bhasma and Lauha Bhasma is extensively used in the treatment of colic pain and various eye diseases. Present review study is tried to establish the role of Lauha Bhasma or Iron oxide Nano-particle (IONP) to cure $H$. pylori-related diseases. Further, this could be safe, effective and cost-effective medicine to eradicate MDR H.Pylori infection. However, this hypothetical study requires in-vitro (culture and 
sensitivity), in-vivo, and clinical trial to design a dose and duration regimen.

\section{ACKNOWLEDGEMENT}

I am very thankful to Dr. Usha Sharma Dr Shuchi Mitra and Dr. Sushma Rawat for providing valuable suggestion and helping in preparation of this manuscript.

\section{REFERANCES}

1. Yadevendra, Y., Vipin, K., Usha, S., \& Chand, S. K.(2006). International Journal of Ayurveda and Pharma Research.

2. Tripthi Indradev.(2010). Elaborated Vaidyaprabha hindi commentary on Chakradatta of Chakrapanidatta, Chaukhambha Sanskrit bhawan, Varanasi, Edition 2010, 27(13),182.

3. Sastri Laxmipati.(2010). Elaborated Vidyotini hindi, commentary on Yogaratnakara, Chaukhabha Prakashan, Varanasi, edition 2010, Shula chikitsa, 14 .

4. Del Valle, J. (2005). Peptic ulcer disease and related disorders. Harrisons Principles of Internal medicine, 16(2), 1746.

5. Yadav, Y., Sharma, K. C., Rajesh, K., \& Arun, S. (2019). An Updated Review on Recent In-Vitro, In-Vivo and Clinical Researches of Avipattikar Churna.

6. Atherton, J.C., \& Blaser, M.J.(2005). Chapter on Helicobactor Pylori Infections, Harrison's principles of Internal Medicine Vol-, McGraw-Hill medical publishing division, $16^{\text {th }}$ edition 2005 , 886-888.

7. Warren, J. R., \& Marshall, B. (1983). Unidentified curved bacilli on gastric epithelium in active chronic gastritis. The lancet, 321(8336), 12731275.

8. Lee, A. (1999). Helicobacter pylori: opportunistic member of the normal microflora or agent of communicable disease?. In Medical Importance of the Normal Microflora (pp. 128-163). Springer, Boston, MA.

9. Mégraud, F. (2005). A humble bacterium sweeps this year's Nobel Prize. Cell, 123(6), 975-976.

10. European Helicobacter pylori Study Group. (1997). Current European concepts in the management of Helicobacter pylori infection. The Maastricht Consensus Report. Gut., 41, 8-13.

11. Chey, W. D., Wong, B. C., \& Practice Parameters Committee of the American College of Gastroenterology. (2007). American College of Gastroenterology guideline on the management of Helicobacter pylori infection. American Journal of Gastroenterology, 102(8), 1808-1825.

12. Selgrad, M., \& Malfertheiner, P. (2012). Commentary: is Helicobacter pylori antibiotic resistance surveillance needed and how can it be delivered?. Alimentary Pharmacology and Therapeutics, 36(2), 197.

13. Ghosh, K., \& Baghel, M. S. (2011). Review of clinical observational studies conducted on 1812 patients of amlapitta at ipgt \& ra, jamnagar. International Journal of Research in Ayurveda \& Pharmacy, 2(5).

14. Sastri, S. (2004). Vidyotini hindi commentary on Madav Nidan of Madhavkara, Part-2, Chaukhambha Sanskrit Bhawan, Varanasi, edition 2004, verse-51/2,171

15. Shirai, M., Kakada, J., Shibata, K., MORSHED, M. G., Matsushita, T., \& Nakazawa, T. (2000). Accumulation of polyphosphate granules in Helicobacter pylori cells under anaerobic conditions. Journal of medical microbiology, 49(6), 513-519.

16. Pathology, R. B. (2003). /Kumar. Cotran, Robbins.

17. Tortora, G.J., Grabowski, S.R.(2003). Principles of Anatomy and physiology, John Wiley and Sons, 10 edition 2003, 899

18. Meining, A., Kroher, G., \& Stolte, M. (1998). Animal reservoirs in the transmission of Helicobacter heilmannii: results of a questionnairebased study. Scandinavian journal of gastroenterology, 33(8), 795-798.

19. Lee, A., \& O'Rourke, J. (1995). The Helicobacter felis mouse model. Helicobacter pylori techniques for clinical diagnoses and basic research. Saunders, London, United Kingdom, 188-205.

20. Andersen, L. P., Nørgaard, A., Holck, S., Blom, J., \& Elsborg, L. (1996). Isolation of a" Helicobacter heilmanii"-like organism from the human stomach. European journal of clinical microbiology \& infectious diseases: official publication of the European Society of Clinical Microbiology, 15(1), 95.

21. Jalava, K., On, S. L., Harrington, C. S., Andersen, L. P., Hänninen, M. L., \& Vandamme, P. (2001). A cultured strain of" Helicobacter heilmannii," a human gastric pathogen, identified as $H$. bizzozeronii: evidence for zoonotic potential of Helicobacter. Emerging infectious diseases, 7(6), 1036.

22. Ertem, D. (2013). Clinical practice: Helicobacter pylori infection in childhood. European journal of pediatrics, 172(11), 1427-1434.

23. Mendall, M. A., Goggin, P. M., Molineaux, N., Levy, J., Toosy, T., Strachan, D., ... \& Northfield, T. C. (1994). Relation of Helicobacter pylori infection and coronary heart disease. Heart, 71(5), 437-439.

24. Markus, H. S., \& Mendall, M. A. (1998). Helicobacter pylori infection: a risk factor for ischaemic cerebrovascular disease and carotid atheroma. Journal of Neurology, Neurosurgery \& Psychiatry, 64(1), 104-107.

25. Gasbarrini, A., Franceschi, F., Armuzzi, A., Ojetti, V., Candelli, M., Torre, E. S., ... \& Gasbarrini, G. 
(1999). Extradigestive manifestations of Helicobacter pylori gastric infection. Gut, 45(suppl 1), I9-I12.

26. Aragona, P., Magazzu, G., Macchia, G., Bartolone, S., Di, G. P., Vitali, C., \& Ferreri, G. (1999). Presence of antibodies against Helicobacter pylori and its heat-shock protein 60 in the serum of patients with Sjögren's syndrome. The Journal of rheumatology, 26(6), 1306-1311.

27. Sacca, S. C., Vagge, A., Pulliero, A., \& Izzotti, A. (2014). Helicobacter pylori infection and eye diseases: a systematic review. Medicine, 93(28).

28. Tripathi, I. D. (2010). Chakradatta of Chakrapanidatta edited with 'Vaidyaprabha'Hindi commentary. Chawkhambha Sanskrit Bhavana, Varanasi.

29. Yadav, Y., Sharma, K. C., Rajesh, K., \& Arun, S. (2019). An Updated Review on Recent In-Vitro, In-Vivo and Clinical Researches of Avipattikar Churna.

30. IARC.(1994). Working group of Carinogenic Risks of Human Infection with H.Pylori, IARC Monogr. Eval Carcinog. Risk Human,61;177-240

31. Malfertheiner, P., Megraud, F., O'Morain, C. A., Atherton, J., Axon, A. T., Bazzoli, F., ... \& ElOmar, E. M. (2012). Management of Helicobacter pylori infection - the Maastricht IV/Florence consensus report. Gut, 61(5), 646-664.

32. Dharmalingam, S., Rao, U. A., Jayaraman, G., \& Thyagarajan, S. P. (2003). Relationship of plasmid profile with the antibiotic sensitivity pattern of Helicobacter pylori isolates from peptic ulcer disease patients in Chennai. Indian journal of medical microbiology, 21(4), 257.

33. Tripthi Indradev.(2010). Elaborated Vaidyaprabha hindi commentary on Chakradatta of Chakrapanidatta, Chaukhambha Sanskrit bhawan, Varanasi, Edition 2010, verse-27/13,182

34. Shah, N.C. (2005). Bharat Bhaisjya Ratanakar, B Jain Publisers Pvt Ltd.Vol 1-5, New Delhi, edition 2005.

35. The Ayurvedic Pharmacopeia of India, Part-1, Volume-7, $1^{\text {st }}$ edition 2008, GOI, New Delhi

36. Rajurkar, N., Kale, B., \& Kantak, S. (2015). Synthesis and characterization of mandur bhasma. Int J Pharm Biol Arch, 6(3), 21-28.

37. Rajput, D., \& Gokarn, R. (2016). Analytical standardization of Mandura Bhasma (incinerated iron oxide). Journal of Indian System of Medicine, 4(2), 77.

38. Sarkar, P. K., Prajapati, P. K., Choudhary, A. K., De, S., \& Ravishankar, B. (2007). A comparative pharmaceutico-pharmaco-clinical study of Lauha Bhasma and Mandura Bhasma wsr to its Panduhara Effect. AYU (An international quarterly journal of research in Ayurveda), 28(1), 11.

39. Mulik, S. B., \& Jha, C. B. (2011). Physicochemical characterization of an Iron based Indian traditional medicine: Mandura Bhasma. Ancient science of life, 31(2), 52.
40. Bhargava, S. C., Reddy, K. C., \& Sastry, G. S. (2012). Identifications studies of Lauha Bhasma by X-ray diffraction and X-ray fluorescence. $A y u, 33(1), 143$.

41. Dr. O. P. Tandon. (1999). Principles of General and Inorganic Chemistry, G.R. Bathala \& sons, Muzaffarnagar edition; 1172-1188

42. Cornell, R. M., \& Schwertmann, U. (2003). The iron oxides: structure, properties, reactions, occurrences and uses. John Wiley \& Sons.

43. Gupta, C.P.(2014). Role of Iron (Fe) in body;IOSR Journal of applied chemistry, 7(11), 38-46

44. Ruebush, S. S., Brantley, S. L., \& Tien, M. (2006). Reduction of soluble and insoluble iron forms by membrane fractions of Shewanella oneidensis grown under aerobic and anaerobic conditions. Appl. Environ. Microbiol., 72(4), $2925-$ 2935.

45. Zakaria, N. H., \& Ahmed, E. A. (2009). Investigation of a possible association between refractory iron deficiency anaemia to an underlying remote helicobacter pylori infection. J Egypt public Health Assoc, 84, 141-68.

46. Dufour, C., Brisigotti, M., Fabretti, G., Luxardo, P., Mori, P. G., \& Barabino, A. (1993). Helicobacter pylori gastric infection and sideropenic refractory anemia. Journal of pediatric gastroenterology and nutrition, 17(2), 225-227.

47. Husson, M. O., Legrand, D. O. M. I. N. I. Q. U. E., Spik, G. E. N. E. V. I. E. V. E., \& Leclerc, H. E. N. R. I. (1993). Iron acquisition by Helicobacter pylori: importance of human lactoferrin. Infection and immunity, 61(6), 2694-2697.

48. Kehl-Fie, T. E., \& Skaar, E. P. (2010). Nutritional immunity beyond iron: a role for manganese and zinc. Current opinion in chemical biology, 14(2), 218-224.

49. Bullen, J. J., Griffiths, E., \& Edmiston, C. E. (1999). Iron and infection: molecular, physiological and clinical aspects.

50. Ratledge, C., \& Dover, L. G. (2000). Iron metabolism in pathogenic bacteria. Annual reviews in microbiology, 54(1), 881-941.

51. Létoffé, S., Heuck, G., Delepelaire, P., Lange, N., \& Wandersman, C. (2009). Bacteria capture iron from heme by keeping tetrapyrrol skeleton intact. Proceedings of the National Academy of Sciences, 106(28), 11719-11724.

52. Senkovich, O., Ceaser, S., McGee, D. J., \& Testerman, T. L. (2010). Unique host iron utilization mechanisms of Helicobacter pylori revealed with iron-deficient chemically defined media. Infection and immunity, 78(5), 1841-1849.

53. Bijlsma, J. J., Waidner, B., van Vliet, A. H., Hughes, N. J., Häg, S., Bereswill, S., ... \& Kusters, J. G. (2002). The Helicobacter pylori homologue of the ferric uptake regulator is involved in acid resistance. Infection and immunity, 70(2), 606-611.

54. Van Vliet, A. H., Stoof, J., Vlasblom, R., Wainwright, S. A., Hughes, N. J., Kelly, D. J., ... \& 
Kist, M. (2002). The role of the ferric uptake regulator (Fur) in regulation of Helicobacter pylori iron uptake. Helicobacter, 7(4), 237-244.

55. Gancz, H., Censini, S., \& Merrell, D. S. (2006). Iron and $\mathrm{pH}$ homeostasis intersect at the level of Fur regulation in the gastric pathogen Helicobacter pylori. Infection and immunity, 74(1), 602-614.

56. Ernst, F. D., Homuth, G., Stoof, J., Mäder, U., Waidner, B., Kuipers, E. J., ... \& van Vliet, A. H. (2005). Iron-responsive regulation of the Helicobacter pylori iron-cofactored superoxide dismutase SodB is mediated by Fur. Journal of bacteriology, 187(11), 3687-3692.

57. Gancz, H., \& Merrell, D. S. (2011). The Helicobacter pylori ferric uptake regulator (Fur) is essential for growth under sodium chloride stress. The Journal of Microbiology, 49(2), 294298.

58. Sharaf, S. M., Abbas, H. S., \& Ismaeil, T. A. (2019). Characterization of spirugenic iron oxide nanoparticles and their antibacterial activity against multidrug-resistant Helicobacter pylori. Egyptian $J$. of Phycol. Vol, 20(2).

59. Dusenbery, D. B. (2009). Living at micro scale: the unexpected physics of being small. Harvard University Press.

60. Becker, K. W., \& Skaar, E. P. (2014). Metal limitation and toxicity at the interface between host and pathogen. FEMS microbiology reviews, 38(6), 1235-1249.

61. Guyton, A. C., \& Hall, J. E. (1986). Textbook of medical physiology (Vol. 548). Philadelphia: Saunders.

62. Triphati, K. D. (2004). Essential of Medical Pharmacology, Jaypee Brother Medical Publisher (P) LTD. New Delhi reprint.

63. Haber, F., \& Weiss, J. (1932). Über die katalyse des hydroperoxydes. Naturwissenschaften, 20(51), 948-950.

64. Koppenol, W. H. (2001). The Haber-Weiss cycle70 years later. Redox Report, 6(4), 229-234.

65. Feng, J., Hu, X., \& Yue, P. L. (2006). Mineralization of Indigo Carmine at Neutral $\mathrm{pH}$ Using Nanocomposite as a Heterogeneous PhotoFenton Catalyst. Studies in surface science and catalysis, 159, 389.

66. Marieb, E. N., \& Hoehn, K. (2010). Human Anatomy and Physiology 8th issue.

67. Mahdy, S. A., Raheed, Q. J., \& Kalaichelvan, P. T. (2012). Antimicrobial activity of zero-valent iron nanoparticles. International Journal of Modern Engineering Research, 2(1), 578-581.

68. Tran, N., Mir, A., Mallik, D., Sinha, A., Nayar, S., \& Webster, T. J. (2010). Bactericidal effect of iron oxide nanoparticles on Staphylococcus aureus. International journal of nanomedicine, 5, 277.

69. Zhang, H., \& Chen, G. (2009). Potent antibacterial activities of $\mathrm{Ag} / \mathrm{TiO} 2$ nanocomposite powders synthesized by a one-pot sol- gel method. Environmental science \& technology, 43(8), 2905-2910.

70. Guichard, Y., Schmit, J., Darne, C., Gaté, L., Goutet, M., Rousset, D., ... \& Fierro, V. (2012). Cytotoxicity and genotoxicity of nanosized and microsized titanium dioxide and iron oxide particles in Syrian hamster embryo cells. Annals of Occupational Hygiene, 56(5), 631-644.

71. Solís-López, M., Durán-Moreno, A., Rigas, F., Morales, A. A., Navarrete, M., \& Ramírez-Zamora, R. M. (2014). Assessment of copper slag as a sustainable Fenton-type Photocatalyst for water disinfection. In Water Reclamation and Sustainability (pp. 199-227). Elsevier.

72. Rezaei, Z. S., Javed, A., Ghani, M. J., Soufian, S., BARZEGARI, F. F., BAYANDORI, M. A., \& Mirjalili, S. H. (2010). Comparative study of antimicrobial activities of $\mathrm{TiO} 2$ and $\mathrm{CdO}$ nanoparticles against the pathogenic strain of Escherichia coli.

73. Zhang, H., \& Chen, G. (2009). Potent antibacterial activities of $\mathrm{Ag} / \mathrm{TiO} 2$ nanocomposite powders synthesized by a one-pot sol- gel method. Environmental science \& technology, 43(8), 2905-2910.

74. Hojo, Y., Okado, A., Kawazoe, S., \& Mizutani, T. (2000). In vivo singlet-oxygen generation in blood of chromium (VI)-treated mice: an electron spin resonance spin-trapping study. Biological trace element research, 76(1), 85-93.

75. Sies, H., Menck, C.F.(1992). Singlet oxygen induced DNA damage. Mutat Res, 275:367-375.

76. Kangatharalingam, N., \& Amy, P. S. (1994). Helicobacter pylori comb. nov. exhibits facultative acidophilism and obligate microaerophilism. Appl. Environ. Microbiol., 60(6), 2176-2179.

77. Sastri, K. (2006). Chaturvedi Gorkhanath elaborated vidyotini hindi commentary on Charak Samhita Vimanastan of Agnivesa, Revised by Caraka \& Dradhabal, Chaukhamba Bharti Academy, Varanasi, edition Part I,--verse-7/14,724735 .

78. Singh, T. R., Gupta, L. N., \& Kumar, N. (2016). Standard manufacturing procedure of Teekshna lauha bhasma. Journal of Ayurveda and integrative medicine, 7(2), 100-108.

79. Joshi, N., Dash, M. K., Dwivedi, L., \& Khilnani, G. D. (2016). Toxicity study of Lauha Bhasma (calcined iron) in albino rats. Ancient science of life, 35(3), 159. 